\title{
Mechanical Evaluation of Bottom Ash from Municipal Solid Waste Incineration Used in Roadbase
}

\author{
Qiang Tang $\mathbb{D}^{1,2,3}$ Fan Gu ${ }^{10},{ }^{4}$ Hui Chen, ${ }^{3}$ Cong Lu, ${ }^{5}$ and Yu Zhang ${ }^{3}$ \\ ${ }^{1}$ Key Laboratory of Ministry of Education for Geomechanics and Embankment Engineering, Hohai University, Nanjing, China \\ ${ }^{2}$ Jiangsu Research Center for Geotechnical Engineering Technology, Hohai University, Nanjing, China \\ ${ }^{3}$ School of Rail Transportation, Soochow University, Suzhou, China \\ ${ }^{4}$ National Center for Asphalt Technology, Auburn University, Auburn, AL, USA \\ ${ }^{5}$ School of Civil Engineering, Suzhou University of Science and Technology, Suzhou, China \\ Correspondence should be addressed to Fan Gu; tracygufan@tamu.edu
}

Received 16 February 2018; Revised 3 July 2018; Accepted 25 July 2018; Published 5 December 2018

Academic Editor: Kirk Hatfield

Copyright (C) 2018 Qiang Tang et al. This is an open access article distributed under the Creative Commons Attribution License, which permits unrestricted use, distribution, and reproduction in any medium, provided the original work is properly cited.

\begin{abstract}
As a by-product from the incineration of municipal solid waste, bottom ash has a broad application prospect of resource utilization. In this study, bottom ash was selected as partial aggregate alternative and used as roadbase materials. The cemented aggregate containing bottom ash was evaluated through both experimental and numerical analysis. According to the results, the unconfined compressive strength of samples increases with the curing time, and the failure strain of sample decreases with the curing time. The unconfined compressive strength and failure strain of samples are influenced by the types of bottom ash. The increase of compressive strength with the curing time can be attributed to that the hydration reaction of cement will be more complete when the curing time is longer. The representative value ( 7 days) of unconfined compressive strength of samples meets the strength requirement $(\geq 2.5 \mathrm{MPa})$ of the road subbase layer of heavy traffic highway in China. Subsequently, the surface settlement decreases with the increase of the modulus and thickness of roadbase and the distance from the centerline, while the settlement increases with vehicle load increasing. The modulus of the roadbase is not the main influences on the pavement settlement, under the condition that the strength of samples meets the requirements. However, increasing the thickness of roadbase can reduce the settlement at the center of the pavement effectively.
\end{abstract}

\section{Introduction}

Nowadays, the amount of municipal solid waste is significantly increasing in China [1, 2]. From 2004 to 2015, the municipal solid wastes increased from 155.1 to 191.4 megatons. Conventional treatment methods for municipal solid waste include reusing and recycling, composting, anaerobic digestion, incineration, and land disposal [3-5]. Among them, incineration treatment is the most effective method in terms of energy saving and reduction of the volume and weight of waste [6-8]. In Holland, the incineration percentage of solid waste reached 40\% in 2000, while in Sweden, Denmark, Luxembourg, Japan, and Switzerland, such incineration percentage even reached $60-80 \%[6,9]$. In China, the incineration percentage of municipal solid wastes also increased from $2.90 \%$ in 2004 to $34.3 \%$ in 2015 . Obviously, incineration technique has become more and more prevalent to dispose municipal solid waste.

However, incineration technique also generates other types of solid wastes, primarily including bottom ash, fly ashes, and air pollution control (APC) ashes [10,11]. Fly ash and APC ash usually consist of high percentage of chlorides, heavy metals, or other organic compounds, which are harmful to environment [12-14], while bottom ash is mainly composed of noncombustible materials such as glass, ceramics, and unburned matter. The amount of chlorides and hazardous chemicals in bottom ash is typically significantly lower than that in fly ash and APC ash [12]. In addition, bottom ash accounts for $25 \%$ of the amount of total municipal solid waste and represents $80 \%$ of the total ash 
[15-17]. Due to the high cost of treatment and disposal, the environment-friendly recycling of bottom ash has attracted more and more attention in recent years [12].

Some studies reported that the recycled bottom ash was applied to many construction projects $[12,18]$. In Germany and France, the recycling rate of bottom ash was more than $60 \%$, and in Denmark and Holland, this rate even reached $80 \%$ [12], while in China, the recycling rate of bottom ash is still low [19]. The municipal solid waste incineration bottom ash is widely used as soil improvement materials, concrete aggregate, and roadbed stuffing [16, 20-24]. In China, bottom ash is mainly used as concrete aggregate, supplementary cementitious material $[25,26]$. These existing studies demonstrated that bottom ash could partially replace natural aggregate, which could save natural resources and energy. Moreover, the cement is capable of fixing the bottom ash-containing contaminant by adsorption or surface complexation, which promotes the environment-friendly recycling of bottom ash $[10,11]$.

To address the aforementioned research needs, this study aimed at recycling the bottom ash from municipal solid waste incineration to partially replacing natural aggregates. The ordinary Portland cement (OPC) was used as a binder material in the bottom ash-aggregate mixture. This study investigated the effects of curing time and mixture ratio on the mechanical behavior of the bottom ash-aggregate mixture. MIDAS GTS was used to simulate the pavement settlement when using the bottom ash in roadbase. The influence factors included the axle load and the modulus and thickness of roadbase. Finally, both the laboratory and simulation results advocated the use of bottom ash in roadbase.

\section{Materials and Methods}

2.1. Materials. The bottom ash used in this study was collected from Taizhou municipal solid waste incineration power plant in Jiangsu Province, China. Approximately 800 tons/day of municipal solid wastes were incinerated for electricity generation in this plant. As a kind of renewable resources, the bottom ash includes the original bottom ash and cracked bottom ash. As shown in Figure 1, original bottom ash was crushed into smaller particles that is called cracked bottom. Four types of limestone aggregates were used in the study, which are labeled as $1 \#, 2 \#, 3 \#$, and 4\#, respectively. The particle size distributions of original bottom and cracked bottom ash and limestone aggregates are shown in Table 1. As presented, 96\% of 1\# aggregates are distributed within the range of $9.5 \mathrm{~mm} \sim 31.5 \mathrm{~mm} ; 95.8 \%$ of 2\# aggregates are within the range of $4.75 \mathrm{~mm} 19 \mathrm{~mm}$; $97.3 \%$ of $3 \#$ aggregates are within the range of $0.075 \mathrm{~mm} \sim 9.5 \mathrm{~mm}$; and $84.5 \%$ of $4 \#$ aggregates are within the range of $0.075 \mathrm{~mm} 4.75 \mathrm{~mm}$. The particles of cracked bottom ash are smaller than the original bottom ash.

The physical properties of original bottom ash and cracked bottom ash and limestone aggregate are presented in Table 2. Note that the current Chinese standard JTG/F20 only requires to measure the apparent density for aggregates. As shown in Table 2, the apparent density of the original bottom ash and cracked bottom ash is less than that of

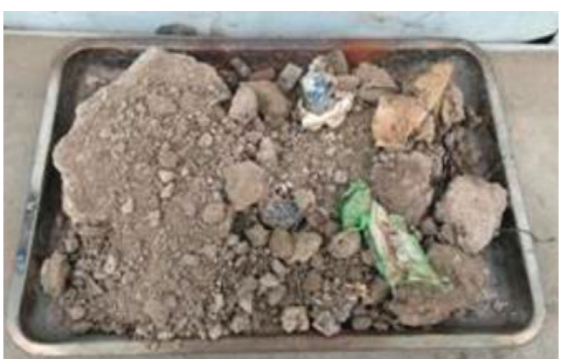

(a)

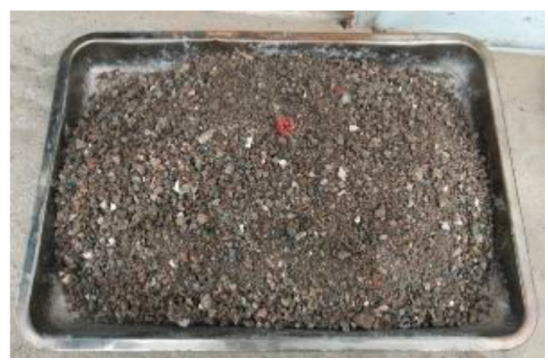

(b)

FIgURE 1: Examples of bottom ash. (a) Original bottom ash. (b) Cracked bottom ash.

TABLE 1: Particle size distribution of 1\#, 2\#, 3\#, and 4\# aggregates, original bottom, and cracked bottom ash (\%).

\begin{tabular}{|c|c|c|c|c|c|c|c|c|c|}
\hline \multirow{2}{*}{ Aggregate } & \multirow{2}{*}{ Unit } & \multicolumn{8}{|c|}{ Particle size $(\mathrm{mm})$} \\
\hline & & 31.5 & 26.5 & 19 & 9.5 & 4.75 & 2.36 & 0.6 & 0.075 \\
\hline $\begin{array}{l}1 \# \\
\text { aggregate }\end{array}$ & $\%$ & 100 & 95.9 & 55 & 4 & 1 & 0.9 & 0.9 & 0.9 \\
\hline $\begin{array}{l}\text { 2\# } \\
\text { aggregate }\end{array}$ & $\%$ & 100 & 100 & 100 & 56 & 4.2 & 0.9 & 0.9 & 0.9 \\
\hline $\begin{array}{l}3 \# \\
\text { aggregate }\end{array}$ & $\%$ & 100 & 100 & 100 & 100 & 92 & 47.3 & 14.2 & 2.7 \\
\hline $\begin{array}{l}4 \# \\
\text { aggregate }\end{array}$ & $\%$ & 100 & 100 & 100 & 100 & 98.5 & 65.8 & 31.3 & 14.0 \\
\hline $\begin{array}{l}\text { Cracked } \\
\text { bottom ash }\end{array}$ & $\%$ & 100 & 100 & 100 & 99.5 & 79.8 & 49.9 & 22.2 & 3.2 \\
\hline $\begin{array}{l}\text { Original } \\
\text { bottom ash }\end{array}$ & $\%$ & 100 & 98.6 & 91.9 & 71.1 & 50.9 & 35.5 & 19.9 & 3.9 \\
\hline
\end{tabular}

limestone aggregate. Due to the porous structure of the bottom ash, the water absorption of original bottom ash and cracked bottom ash are much higher than that of the limestone aggregates. According to the JTGE42-2005, the crushing value is an index to evaluate the mechanical properties of aggregates, which describes the resistance of aggregate to crushing under the increasing load. The crushing values of the original bottom ash and cracked bottom ash are over $30 \%$, which are also greater than that of the limestone aggregates. Apparently, the hardness of the original bottom ash and cracked bottom are lower than that of the limestone aggregates.

As a binder material, the commercially available ordinary Portland cement (OPC) 42.5 was prepared, which consisted of $6 \%-15 \%$ active additive and $85 \%-94 \%$ cement. The cement consisted of $60.48 \% \mathrm{CaO}, 20.85 \% \mathrm{SiO}_{2}, 5.71 \%$ 
TABLE 2: Physical properties of aggregates.

\begin{tabular}{lcccc}
\hline Aggregate & Sizes $(\mathrm{mm})$ & Crushing value $(\%)$ & Apparent density $\left(\mathrm{g} / \mathrm{cm}^{3}\right)$ & Water absorption rate $(\%)$ \\
\hline Standard (JTG E42-2005) & T0302-2005 & T0350-2005 & T0328-2005 & T0330-2005 \\
\hline \multirow{4}{*}{ Original bottom ash } & $(2.36 \sim 4.75)$ & 30.6 & 2.412 & 9.647 \\
& $(4.75 \sim 9.5)$ & 32.5 & 2.458 & 7.74 \\
& $(9.5 \sim 19.0)$ & 33.1 & 2.318 & 6.23 \\
Cracked bottom ash & $(\geq 19)$ & 43.6 & 2.253 & 6.75 \\
\hline \multirow{2}{*}{ Limestone aggregate } & $(2.36 \sim 4.75)$ & 32.3 & 2.468 & 8.89 \\
& $(4.75 \sim 9.5)$ & 34.7 & 2.402 & 6.41 \\
& $(2.36 \sim 4.75)$ & 25.3 & 2.733 & 0.81 \\
& $(9.75 \sim 9.5)$ & 18.2 & 2.715 & 0.62 \\
& $(\geq 19.0)$ & 22.6 & 2.726 & 0.74 \\
\end{tabular}

$\mathrm{Al}_{2} \mathrm{O}_{3}, 3.33 \% \mathrm{Fe}_{2} \mathrm{O}_{3}, 2.28 \% \mathrm{MgO}, 2.84 \% \mathrm{SO}_{3}$, and $1.43 \%$ $\mathrm{Na}_{2} \mathrm{O}[10]$.

2.2. Method. The aggregate-bottom ash mixture consists of limestone aggregates and cracked bottom ash or original bottom ash, in which the cracked bottom ash and original bottom ash account for $20 \%$ of the weight of limestone aggregate [27]. The aggregate-bottom ash mixtures are recorded as PS-20 and YZ-20 as shown in Table 3. Note that the current Chinese standard JTG/F20 recommends using mass fraction in the mix design. According to Liu et al., the control sample without bottom ash is recoded as LZ-0 [27]. With the bottom ash joining, the number of feed hopper increases accordingly. Therefore, reducing variation of the aggregate yields fast construction speed, simple operation, and low construction cost. As shown in Table 1, the particle size distribution of $3 \#$ aggregate is similar to cracked bottom ash. With the amount of cracked bottom ash kept constant, the $3 \#$ aggregate is replaced by cracked bottom ash. The combined aggregate is simply regarded as PSS-20. The proportion of PS-20, YZ-20, and PSS-20 combined aggregates is shown in Table 3. As shown in Figure 2, the gradation of different designed mixtures (LZ-0, PS-20, YZ-20, and PSS-20) is similar to each other [27], which all meet the requirement (JTG D50-2006). In addition, the cement content accounts for $4 \%$ of combined aggregates. According to JTG E51-2009, the maximum dry density and the optimum water content of PS-20, YZ-20, and PSS-20 combined aggregates with cement content $4 \%$ were determined by the compaction tests. The maximum dry density of LZ-0, PS-20, YZ-20, and PSS-20 is $2.401 \mathrm{~g} / \mathrm{cm}^{3}, 2.293 \mathrm{~g} / \mathrm{cm}^{3}, 2.293 \mathrm{~g} / \mathrm{cm}^{3}$, and $2.308 \mathrm{~g} / \mathrm{cm}^{3}$, respectively. The corresponding optimum water contents are 5.3\%, 5.1\%, 5.1\%, and 5.2\% [27].

Limestone aggregate, cracked bottom ash, original bottom ash, and OPC samples were oven-dried at $105^{\circ} \mathrm{C}$ for 24 hours $(h)$ (101-A, Leao, China). Subsequently, they were cooled down to room temperature in a desiccator. In order to mix thoroughly, the limestone aggregates and cement were first homogenized with cracked bottom ash or original bottom ash at three different ratios (as shown in Table 3 by dry mass) manually in the vessel. According to the optimum water content, the distilled water produced by a water distillation apparatus (JYCS-0.02 T, China) was added slowly into the dry mix for the mixing process. After the
TABle 3: Proportion of combined aggregates (\%).

\begin{tabular}{|c|c|c|c|c|c|c|}
\hline \multirow{2}{*}{$\begin{array}{l}\text { Combined } \\
\text { aggregates }\end{array}$} & \multicolumn{4}{|c|}{$\begin{array}{l}\text { Limestone } \\
\text { aggregate }\end{array}$} & \multirow{2}{*}{$\begin{array}{l}\text { Crushed } \\
\text { bottom } \\
\text { ash }\end{array}$} & \multirow{2}{*}{$\begin{array}{c}\text { Original } \\
\text { bottom } \\
\text { ash }\end{array}$} \\
\hline & $1 \#$ & $2 \#$ & 3\# & $4 \#$ & & \\
\hline PS-20 & 47 & 14.7 & 6 & 15.6 & 16.7 & 1 \\
\hline YZ-20 & 42.2 & 14.6 & 8.4 & 18.1 & 1 & 16.7 \\
\hline PSS-20 & 47 & 14.7 & 1 & 21.6 & 16.7 & 1 \\
\hline
\end{tabular}

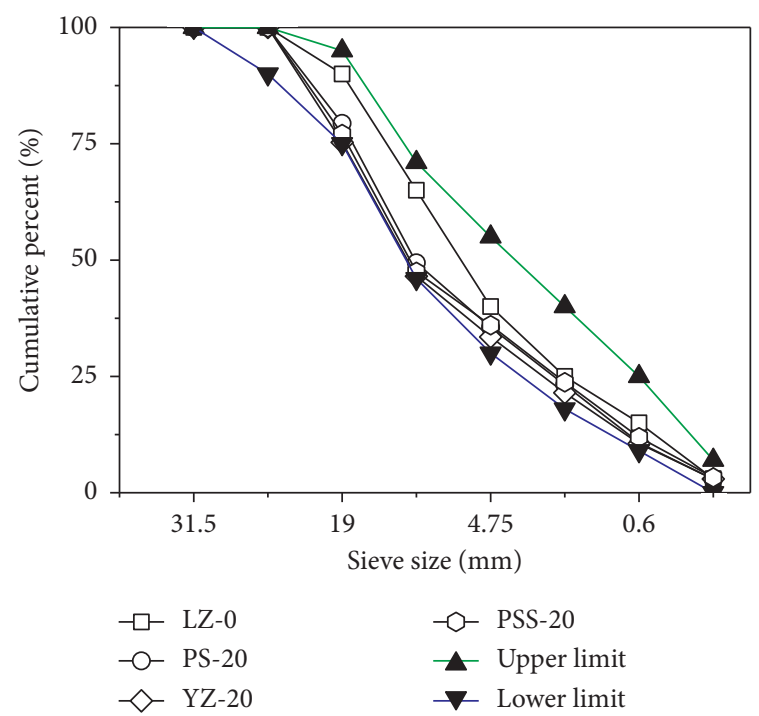

Figure 2: Grain size distributions of LZ-0, PS-20, YZ-20, and PSS20 and standard limits.

mixing procedure, the mixture was transferred into the molds ( $\Phi 150 \mathrm{~mm} \times h 150 \mathrm{~mm}$, Boyuan, China) with $98 \%$ of the maximum dry density at the optimum moisture content. Afterwards, the samples were demolded and wrapped by the polyethylene film. After the period, the mixtures were cured ( $\geq 95 \%$ humidity, $20 \pm 2^{\circ} \mathrm{C}$ ) for 7,14 , and 28 days in the standard curing room (BYS-40, Huanan, China).

Electrohydraulic pressure-testing machine (DYE-2000, Huaxi, China) was used to obtain the compressive strength $\left(f_{\text {cu }}\right)$ of samples. The diameter of loading platform was $15 \mathrm{~cm}$, and the range was fixed at $0 \sim 20000 \mathrm{kN}$ during the test. Total maximum loads were recorded, and the compressive strength was determined using the following formula: 


$$
f_{\mathrm{cu}}=\frac{F}{A},
$$

where $F$ is the total maximum load $(N)$ and $A$ is the area of loaded surface $\left(\mathrm{mm}^{2}\right)$ [1]. Meanwhile, the failure strain $\left(\varepsilon_{\mathrm{f}}\right)$ was measured by displacement meter (KTR11, MIRAN, China). Six replicates were analyzed for each trial.

2.3. Numerical Simulation Model. The roadbase is a supporting layer for road structure. Its main function is to bear the traffic load and disperse the stress generated from pavement surface to underlying layers [28-31]. At present, semirigid base course materials (e.g., cement-, lime-, or fly ash-stabilized aggregates) are widely used in highway construction.

This research adopts the MIDAS/GTS finite element software to simulate cemented aggregate containing bottom ash used in ordinary municipal roadbase. The influence of mix proportion, roadbase thickness, and vehicle load on the structural deformation of the road surface is analyzed. In this paper, the schematic plot of road structure is shown in Figure 3 . The simulation was made on an axisymmetric finite element model [32].

In this model, the road width is 5 meters. The calculation range of the soil foundation is triple the distance of the half road surface. The calculation depth of the model is from the pavement to 3 meters below the surface in the model. The pavement structure consists of some layers as follows: asphalt layer, cement-treated aggregate containing bottom ash, and soil foundation. The basic dimensions and parameter of model (constitutive model, thickness, and basic properties of each layer) are shown in Table 4.

In pavement structure design, it is generally assumed that the axial load is uniformly distributed on the contact area [33]. In BZZ-100 standard axle load, axle load is $100 \mathrm{kN}$ and contact pressure is $0.7 \mathrm{MPa}$. The contact area of wheels and road surface is $0.134 \mathrm{~m}^{2}$ (JTG D50-2006). The road position is shown in Figure 3, and the radius is $0.152 \mathrm{~m}$ in a single round contact.

The subsidence of the simulated surface of the road is only caused by the traffic axle load. Model boundary conditions are that the bottom boundary is completely fixed and that the side boundary is horizontal fixed. The model assumes this simulation is a plane strain problem.

Note that the development of elastic modulus may be inferred from the characteristics of strength development. Lim and Dan investigated relationship between the measured compressive strength and elastic modulus of cemented aggregate containing bottom ash mixtures [34]. Equation (2) is used for predicting elastic modulus of cemented aggregate containing bottom ash materials [34]:

$$
E=635.26 \cdot(16.0256 w)^{1.5} \cdot\left(0.0069 f_{\mathrm{cu}}\right)^{0.75},
$$

where $E$ is the elastic modulus (MPa); $w$ is the mixture density $\left(\mathrm{g} / \mathrm{cm}^{3}\right)$; and $f_{\mathrm{cu}}$ is the unconfined compressive strength ( $\mathrm{MPa}$ ) after 28 days' curing. The elastic modulus is applied to the numerical simulation in this paper.

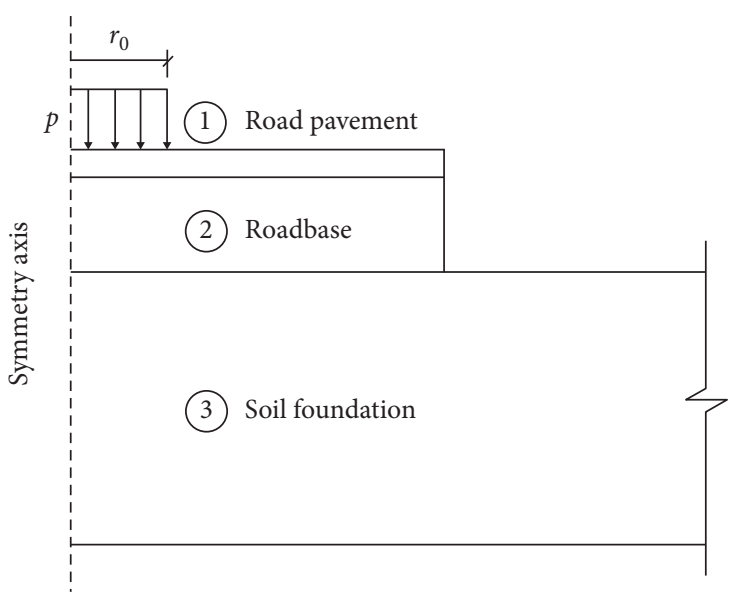

Figure 3: Schematic plot of road structure.

\section{Experimental Results and Analysis}

The unconfined compressive strength values and the failure strain of the cemented aggregate containing bottom ash sample under different curing periods are presented in Figures 4 and 5, respectively.

The unconfined compressive strength of samples increase with the curing time, while the failure strain of samples decrease with the curing time. The unconfined compressive strength and failure strain of samples are also influenced by the types of bottom ash. Compared to the 7 days' curing, the compressive strength of LZ-0, YZ-20, PS20 , and PSS-20 after 14 days' curing increased by $47.8 \%$, $23.9 \%, 31.1 \%$, and $30.3 \%$, and the failure strain of YZ-20, PS20 , and PSS-20 decreased by $20.6 \%, 16.8 \%$, and $22.9 \%$. After 28 days' curing, the compressive strength of LZ-0, YZ-20, PS-20, and PSS-20 increased by $73.9 \%, 49.9 \%, 41.7 \%$, and $47.8 \%$, and the failure strain of YZ-20, PS-20, and PSS-20 decreased by $27.3 \%, 22.5 \%$, and $21.1 \%$.

Figures 4 and 5 show that the compressive strength of mixtures increases and the failure strain decreases with the curing time. This is because the hydration reaction is more adequate with a longer curing time. During the period of cement hydration reaction, two processes are involved. One is through-solution hydration, which involves several factors such as dissolution of anhydrous compounds into their ionic constituents, formation of hydrates in the solution, and eventual precipitation of hydrates from the supersaturated solution. The other is solid-state hydration of cement, and the reactions occur directly at the surface of the hydrous cement compounds. During this period, no compounds dissolve into solution. In the early stage of cement hydration, through-solution hydration is dominant. At the poststage of cement hydration, the hydration of residual cement particles may occur by the solid-state reactions, and the migration of ions in the solution becomes restricted [35]. As presented in Figure 4, LZ-0 has higher compressive strength values than other materials at all the three curing times. The reason is that the strength of the bottom ash is lower than that of the limestone aggregate, and the partial replacement of limestone aggregate 
TABle 4: Parameters of finite element model.

\begin{tabular}{lccc}
\hline Material & (1) & (2) & (3) \\
& Asphalt mixture & Cemented aggregate containing bottom ash & Silty clay \\
\hline Constitutive model & Elasticity & Elasticity & 2.42 \\
Thickness $(\mathrm{m})$ & 0.18 & 0.4 & 17.4 \\
Bulk density $\left(\mathrm{kN} / \mathrm{m}^{3}\right)$ & 19.6 & 22.9 & 22 \\
Elasticity modulus $(\mathrm{MPa})$ & 1400 & 13823 & 24 \\
Cohesive force $(\mathrm{kPa})$ & $/$ & $/$ & 30 \\
Internal friction angle $\left(^{\circ}\right)$ & $/$ & 0.2 & 0.32 \\
Poisson's ration & 0.25 & $/$ & 30 \\
\hline
\end{tabular}

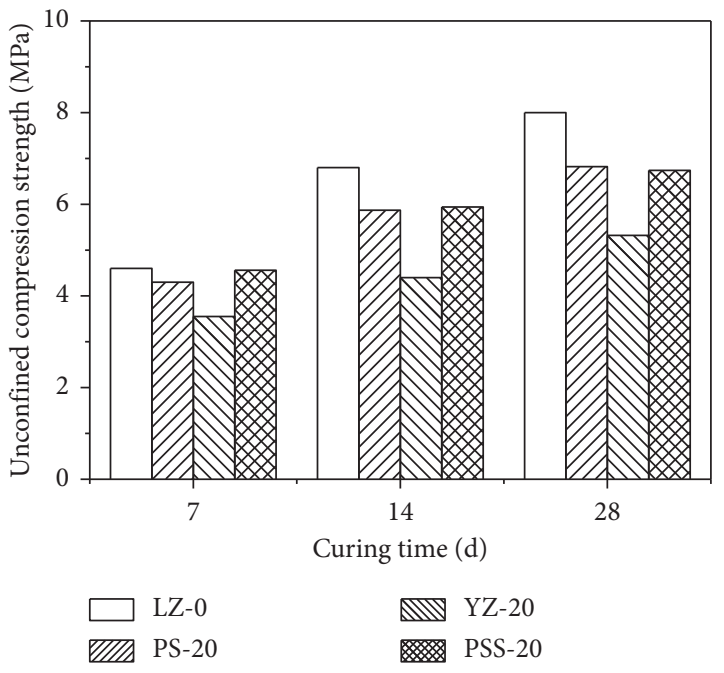

FIgURE 4: The unconfined compression strength of samples under different conditions (mixture ratio and curing time).

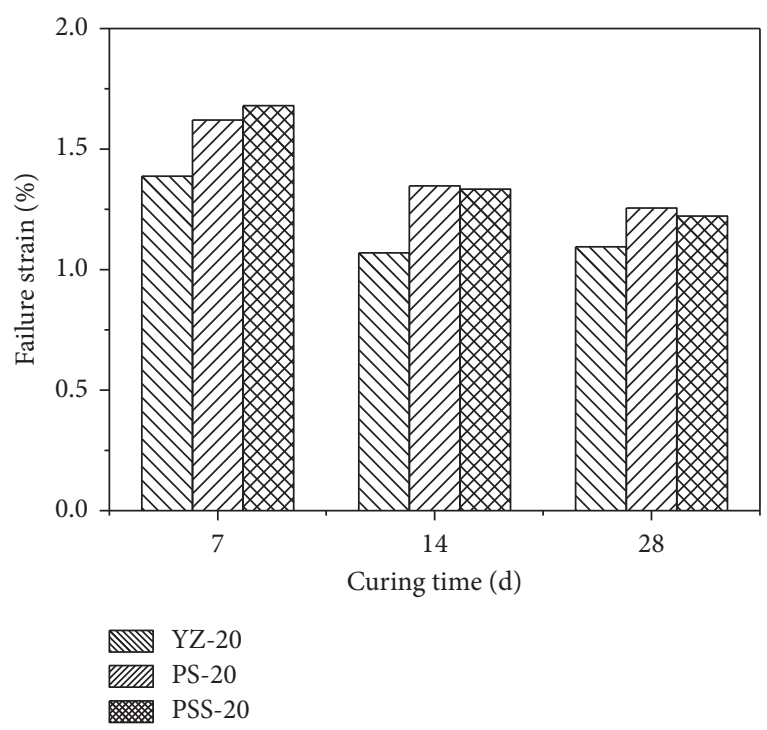

FIGURE 5: The failure strain of samples under different conditions (mixture ratio and curing time).

affects the compressive strength of the sample. According to Table 2, the crushing value of bottom is lower than the limestone aggregate, which further explains the strength of LZ-0 is higher than other samples [27].
The unconfined compressive strength of mixtures and the failure strain are influenced by the types of bottom ash. Compared to the YZ-20 samples, PS-20 samples and PSS-20 samples have higher strength under the same condition. This is because PS-20 samples and PSS-20 samples have more 1\# and 2\# limestone aggregate than YZ-20 samples from Table 3. The strength of the granular material grows with the increase of the maximum particle size, especially for comparable gradation curves [36]. The unconfined compressive strength of samples PSS-20 is slightly higher than that of samples PS20, under the same condition. According to Table 3, PSS-20 has more fine aggregate than PS-20. The fine aggregate has a certain viscosity and plasticity, which will affect the suction in the structure. Meanwhile, the increase of fine particle content results in a higher suction and pore-filling degree and increases the stability between coarse aggregates [22], which further explains that the unconfined compressive strength of samples PSS-20 is slightly higher. Because of premature destruction of large-sized original bottom, the failure strain of the original bottom ash samples is lower than that of the cracked bottom ash samples at the same age.

When the bottom ash content is $20 \%$ and the cement content is $4 \%$, the representative value ( 7 days) of the unconfined compressive strength are 3.35 4.56 MPa, which can meet the strength requirement $(\geq 2.5 \mathrm{MPa})$ of the road subbase layer of heavy traffic highway in China. Under the same condition, the samples containing cracked bottom ash also meet the strength requirements $(\geq 3.5 \mathrm{MPa})$ of the subbase layer and the base layer (JTG/T F20-2015).

\section{Simulation Results and Analysis}

This research used the cement-treated aggregate containing bottom ash as roadbase and explored the influence of base modulus, base thickness, and vehicle load on settlement deformation of pavement.

4.1. Analysis of the Influence of Roadbase Modulus. Due to the cemented aggregate containing bottom ash sample with different conditions, the elasticity moduli of roadbase also vary in most cases. According to the experimental results, the elasticity moduli of cemented aggregate containing bottom ash of LZ-0, PSS-20, PS-20, and YZ-20 after 28 days' curing are $17267 \mathrm{MPa}, 14311 \mathrm{MPa}, 13823 \mathrm{MPa}$, and $11867 \mathrm{MPa}$. Figure 6 shows the surface settlement of pavement using different roadbase materials. 


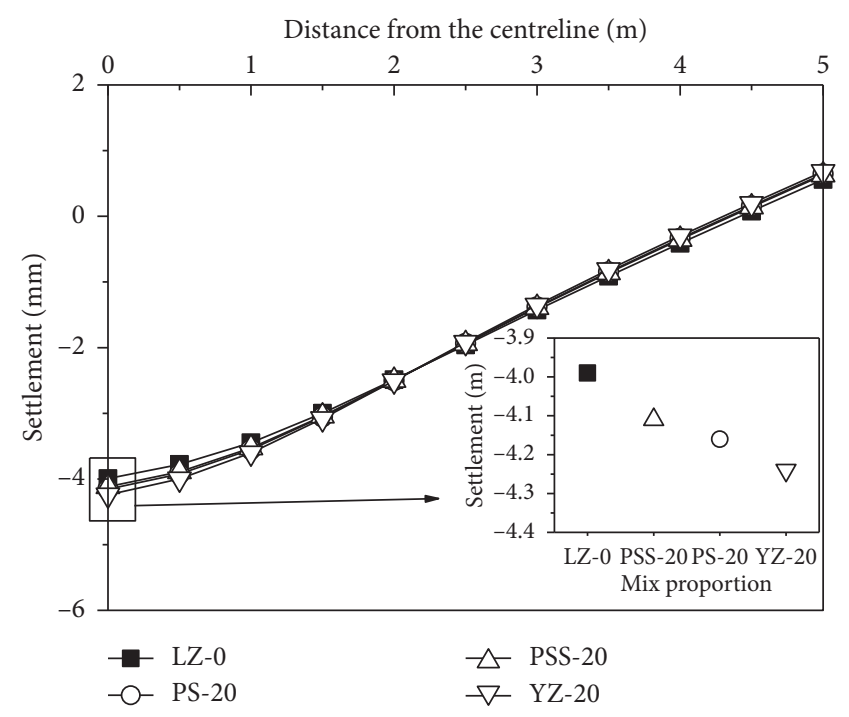

Figure 6: Settlement of the pavement with different base materials.

The surface settlement of the pavement decreases when increasing the elastic modulus and also decreases when the distance is away from the load center. Compared to the load center, the settlement of pavement that is 2.5 meter away from the center reduces by $50 \%$ approximately, and the settlement at the edge decreases by $115-145 \%$. Compared to LZ-0, the use of YZ-20, PS-20, and PSS-20 increases the settlement of pavements at the load center by $6.2 \%, 4.1 \%$, and $3.2 \%$. This indicates that different combinations of aggregates (LZ-0, YZ-20, PS-20, and PSS-20) have negligible effects on pavement settlement. Therefore, the modulus of the roadbase is not the primary factor affecting the pavement settlement, if the base material meets the standard requirements.

4.2. Analysis of the Influence of Roadbase Thickness. According to the JTG D50-2006, the minimum compaction thickness of the single cemented structure layer is $150 \mathrm{~mm}$. In this paper, the base and subbase layer are merged into one layer. The designed thickness of the roadbase layer is $300 \mathrm{~mm}, 400 \mathrm{~mm}$, and $500 \mathrm{~mm}$, respectively. The settlement of pavement with different thickness of the roadbase layer is shown in Figure 7.

The surface settlement of the pavement with different roadbase thicknesses decreases with increasing roadbase thickness and distance away from the centerline. Compared to the center settlement for $300 \mathrm{~mm}$ thick roadbase, the center settlement for $400 \mathrm{~mm}$ and $500 \mathrm{~mm}$ thick roadbase decreases by $15.8 \%$ and $27.9 \%$, respectively. Compared to the surface settlement at the center, the settlement at the edge with $300 \mathrm{~m}$, $400 \mathrm{~mm}$, and $500 \mathrm{~mm}$ roadbase thickness decreases by $116.5 \%, 115.5 \%$, and $109.9 \%$, respectively. The influence of the thickness of roadbase on the reduction of the surface settlement is more effective than the roadbase modulus.

4.3. Analysis of the Influence of Traffic Load. Considering the influence of traffic load on the settlement of the pavement,

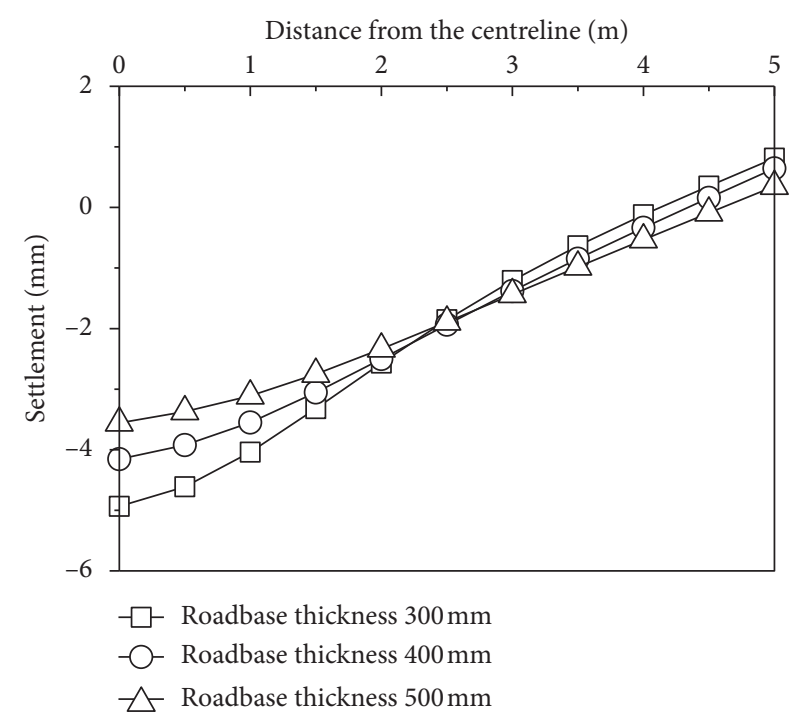

Figure 7: Settlement of the pavement with different roadbase thicknesses.

the designed axle load of the vehicle is $p=0.7 \mathrm{MPa}$ (BZZ-100 standard axle load), $p=1.05 \mathrm{MPa}$ (overload 50\%), and $p=$ 1.4 $\mathrm{MPa}$ (overload 100\%). The settlement of pavements with different traffic loads are shown in Figure 8.

The surface settlement of the pavement with different loads decreases with increasing the distance away from the centerline and increases with increasing the traffic load. Compared to the surface settlement at the center, the settlement of the pavement (2.5 meter away from the center) with standard axle load, overload $50 \%$, and overload $100 \%$ increases by $53.4 \%, 53.5 \%$, and $52.6 \%$; the settlement of the pavement at the edge with standard axle load, overload $50 \%$, and overload $100 \%$ increases $115.5 \%, 116.0 \%$, and $116.7 \%$. Compared to the surface settlement with BZZ-100 standard axle load, the surface settlement with overload 50\%, 100\% increases by $51.2 \%, 103.7 \%$. Under this scenario, the pavement settlement at the centerline $o$ is linearly proportional to the axle load.

\section{Conclusions}

(1) Municipal solid waste bottom ash is suitable to use as roadbase materials to partially replace aggregates. The physical properties and the designed gradation of aggregate-bottom ash mixtures (LZ-0, PS-20, YZ-20, and PSS-20) meet the standard requirements.

(2) The unconfined compressive strength of cementtreated aggregate containing bottom ash samples increases with curing time, and the failure strain decreases with curing time. Under the same condition, the strength of samples with original bottom ash was significantly lower than that within cracked bottom ash samples. The unconfined compressive strength representative value (7 days) could meet the strength requirement of the subbase and base layer of heavy traffic highway in China. 


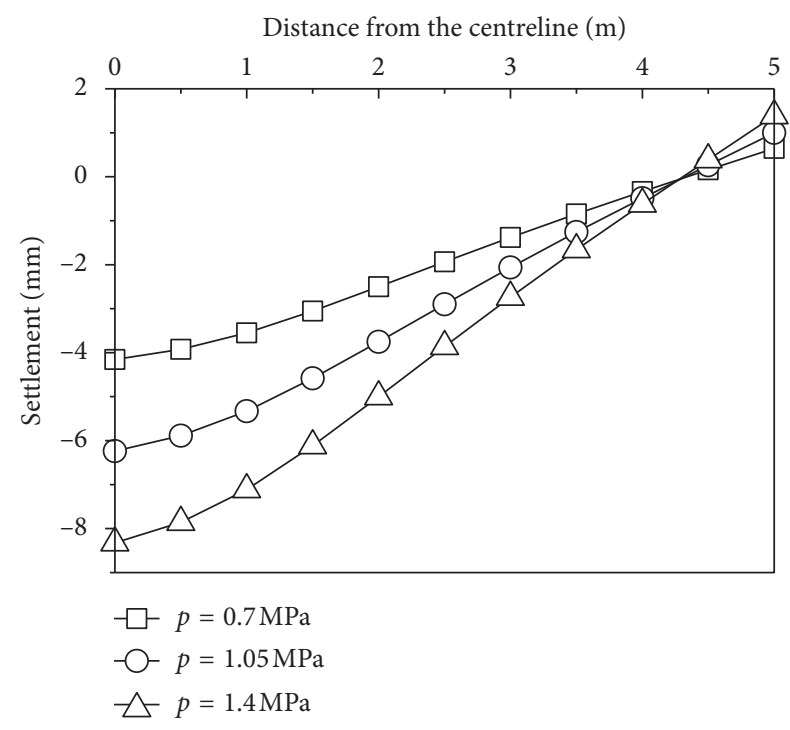

Figure 8: Settlement of the pavement with different axle loads.

(3) The surface settlement decreases with the increase of base modulus, base thickness, and distance away from the centerline, but increases with increasing traffic loads. The modulus of the roadbase was not the primary factor affecting the pavement settlement, if the base material meets the standard requirements. The influence of the thickness of roadbase on the reduction of surface settlement is more effective than the roadbase modulus.

\section{Data Availability}

The data used to support the findings of this study are available from the corresponding author upon request.

\section{Conflicts of Interest}

The authors declare that there are no conflicts of interest regarding the publication of this paper.

\section{Acknowledgments}

This research was supported by the National Nature Science Foundation of China (51708377 and 41630633), Natural Science Foundation of Jiangsu Province (BK20170339), China Postdoctoral Science Foundation funded project (2016M591756), Natural Science Fund for Colleges and Universities in Jiangsu Province (17KJB560008), Jiangsu Planned Projects for Postdoctoral Research Funds (1601175C), and project from Jiangsu Provincial Department of Housing and Urban-Rural Development (2016ZD18). This research was also supported by the Jiangsu Provincial Transport Bureau (2016T05), Six Talent Peaks Project in Jiangsu Province, China (2015-JNHB-018), and Bureau of Housing and Urban-Rural Development of Suzhou.

\section{References}

[1] Q. Tang, W. Liu, H. Y. Wang, R. Cheng, and Y. F. Qian, "Membrane behavior of bentonite-amended Fukakusa clay under K, Na and Ca solutions," Journal of Central South University, vol. 23, no. 12, pp. 3122-3131, 2016.

[2] Q. Tang, T. Katsumi, T. Inui, and Z. Z. Li, "Influence of pH on the membrane behavior of bentonite amended Fukakusaclay," Separation and Purification Technology, vol. 141, pp. 132-142, 2015.

[3] Q. Tang, F. Gu, Y. Zhang, Y. Q. Zhang, and J. L. Mo, "Impact of biological clogging on the barrier performance of landfill liners," Journal of Environmental Management, vol. 222, pp. 44-53, 2018.

[4] Q. Tang, H. J. Kim, K. Endo, T. Katsumi, and T. Inui, "Size effect on lysimeter test evaluating the properties of construction and demolition waste leachate," Soils and Foundations (JGS), vol. 55, no. 4, pp. 720-736, 2015.

[5] Q. Tang, T. Katsumi, T. Inui, and Z. Z. Li, "Membrane behavior of bentonite amended compacted clay," Soils and Foundations (JGS), vol. 54, no. 3, pp. 329-344, 2014.

[6] H. U. Hartenstein and M. Horvay, "Overview of municipal waste incineration industry in west Europe (based on the German experience)," Journal of Hazardous Materials, vol. 47, no. 1-3, pp. 19-30, 1996.

[7] Y. L. Galiano, C. F. Pereira, and J. Vale, "Stabilization/ solidification of a municipal solid waste incineration residue using fly ash-based geopolymers," Journal of Hazardous Materials, vol. 185, no. 1, pp. 373-381, 2011.

[8] K. Anastasiadou, K. Christopoulos, E. Mousios, and E. Gidarakos, "Solidification/stabilization of fly and bottom ash from medical waste incineration facility," Journal of Hazardous Materials, vol. 207-208, no. 6, pp. 165-170, 2012.

[9] Waste treatment in Japan, Ministry of Environment, Waste Management and Recycling Unit, 2011, in Japanese.

[10] Q. Tang, Y. Liu, F. Gu, and T. Zhou, "Solidification/ stabilization of fly ash from a municipal solid waste incineration facility using Portland cement," Advances in Materials Science and Engineering, vol. 2016, Article ID 7101243, 10 pages, 2016.

[11] Q. Tang, Y. Zhang, Y. F. Gao, and F. Gu, "Use of cementchelated, solidified, municipal solid waste incinerator (MSWI) fly ash for pavement material: mechanical and environmental evaluations," Canadian Geotechnical Journal, vol. 54, no. 11, pp. 1553-1566, 2017.

[12] M. Margallo, M. B. M. Taddei, A. Hernández-Pellón, R. Aldaco, and A. Irabien, "Environmental sustainability assessment of the management of municipal solid waste incineration residues: a review of the current situation," Clean Technologies and Environmental Policy, vol. 17, no. 5, pp. 1333-1353, 2015.

[13] Q. Tang, F. Gu, Y. F. Gao, T. Inui, and T. Katsumi, "Desorption characteristics of $\mathrm{Cr}(\mathrm{III}), \mathrm{Mn}(\mathrm{II})$ and $\mathrm{Ni}(\mathrm{II})$ in contaminated soil using citric acid and citric acid containing wastewater," Soils and Foundations (JGS), vol. 58, no. 1, pp. 50-64, 2018.

[14] Q. Tang, X. W. Tang, M. M. Hu, Z. Z. Li, Y. M. Chen, and P. Lou, "Removal of Cd(II) from aqueous solution with activated Firmiana Simplex Leaf: behaviors and affecting factors," Journal of Hazardous Materials, vol. 179, no. 1-3, pp. 95-103, 2010.

[15] D. S. Kosson, H. A. V. D. Sloot, and T. T. Eighmy, "An approach for estimation of contaminant release during 
utilization and disposal of municipal waste combustion residues," Journal of Hazardous Materials, vol. 47, no. 1-3, pp. 43-75, 1996.

[16] C. C. Wiles, "Municipal solid waste combustion ash: state-ofthe-knowledge," Journal of Hazardous Materials, vol. 47, no. 1-3, pp. 325-344, 1996.

[17] R. Forteza, M. Far, C. Seguí, and V. Cerda, "Characterization of bottom ash in municipal solid waste incinerators for its use in road base," Waste Management, vol. 24, no. 9, pp. 899-909, 2004.

[18] C. Ferreira, A. Ribeiro, and L. Ottosen, "Possible applications for municipal solid waste fly ash," Journal of Hazardous Materials, vol. 96, no. 2, pp. 201-216, 2003.

[19] D. Q. Zhang, S. K. Tan, and R. M. Gersberg, "Municipal solid waste management in China: status, problems and challenges," Journal of Environmental Management, vol. 91, no. 8, pp. 1623-1633, 2010.

[20] S. Sakai, S. E. Sawell, A. J. Chandler, T. T. Eighmy, D. S. Kosson, and J. Vehlow, "World trends in municipal solid waste management," Waste Management, vol. 16, no. 5-6, pp. 341-350, 1996.

[21] R. Sinquin, G. Valentis, and I. Pari, "Testing and use of bottom ash in France," in Proceedings of 7th International Conference on Municipal Solid Waste Combustor Ash Utilization, pp. 32-48, Arlington, VA, USA, 1997.

[22] U. Müller and K. Rübner, "The microstructure of concrete made with municipal waste incinerator bottom ash as an aggregate component," Cement and Concrete Research, vol. 36, no. 8, pp. 1434-1443, 2006.

[23] M. Arm, "Variation in deformation properties of processed MSWI bottom ash: results from triaxial tests," Waste Management, vol. 24, no. 10, pp. 1035-1042, 2004.

[24] M. Abdulahi, "Municipal solid waste incineration bottom ash as road construction material," AU Journal of Technology, vol. 13, no. 2, pp. 121-128, 2009.

[25] X. G. Li, Y. Lv, B. G. Ma, Q. B. Chen, X. B. Yin, and S. W. Jian, "Utilization of municipal solid waste incineration bottom ash in blended cement," Journal of Cleaner Production, vol. 32, pp. 96-100, 2012.

[26] H. Zhang, P. J. He, L. M. Shao, and X. J. Li, "Leaching behavior of heavy metals from municipal solid waste incineration bottom ash and its geochemical modeling," Journal of $\mathrm{Ma}$ terial Cycles and Waste Management, vol. 10, no. 1, pp. 7-13, 2008.

[27] D. Liu, L. Li, and H. Cui, "Pavement performance of cement stabilized municipal solid waste incineration bottom ash aggregate and crushed stones," Journal of Tongji University, vol. 43, no. 3, pp. 405-415, 2015.

[28] F. Gu, Y. Zhang, C. V. Droddy, R. Luo, and R. L. Lytton, "Development of a new mechanistic empirical rutting model for unbound granular material," Journal of Materials in Civil Engineering, vol. 28, no. 8, article 04016051, 2016.

[29] J. Zhang, J. Peng, J. Li, and J. Zheng, "Characterization of stress and moisture-dependent resilient behaviour for compacted clays in South China," Road Materials and Pavement Design, pp. 1-14, 2018.

[30] J. Zhang, J. Li, Y. Yao, J. Zheng, and F. Gu, "Geometric anisotropy modeling and shear behavior evaluation of graded crushed rocks," Construction and Building Materials, vol. 183, pp. 346-355, 2018.

[31] F. Gu, H. Sahin, X. Luo, R. Luo, and R. Lytton, "Estimation of resilient modulus of unbound aggregates using performancerelated base course properties," Journal of Materials in Civil Engineering, vol. 27, no. 6, article 04014188, 2014.
[32] F. Gu, X. Luo, R. Luo, R. L. Lytton, E. Y. Hajj, and R. V. Siddharthan, "Numerical modeling of geogridreinforced flexible pavement and corresponding validation using large-scale tank test," Construction and Building $\mathrm{Ma}$ terials, vol. 122, pp. 214-230, 2016.

[33] K. Himeno, T. Kamijima, T. Ikeda, and T. Abe, "Distribution of tire contact pressure of vehicles and its influence on pavement distress," in Proceedings of Eighth International Conference on Asphalt Pavements Federal Highway Administration, Seattle, WA, USA, August 1997.

[34] S. Lim and G. Z. Dan, "Estimation of the compressive strength and modulus of elasticity of cement-treated aggregate base materials," Transportation Research Record Journal of Transportation Research Board, vol. 1837, no. 1, pp. 30-38, 2003.

[35] P. K. Mehta and P. J. M. Monteiro, Concrete: Microstructure, Properties, and Materials, McGraw-Hill Education, New York City, NY, USA, 4th edition, 2014.

[36] P. Chindaprasirt, S. Hatanaka, N. Mishima, Y. Yuasa, and T. Chareerat, "Effects of binder strength and aggregate size on the compressive strength and void ratio of porous concrete," International Journal of Minerals, Metallurgy and Materials, vol. 16, no. 6, pp. 714-719, 2009. 


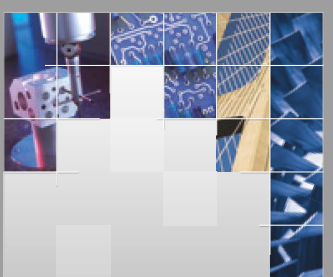

\section{Enfincering}
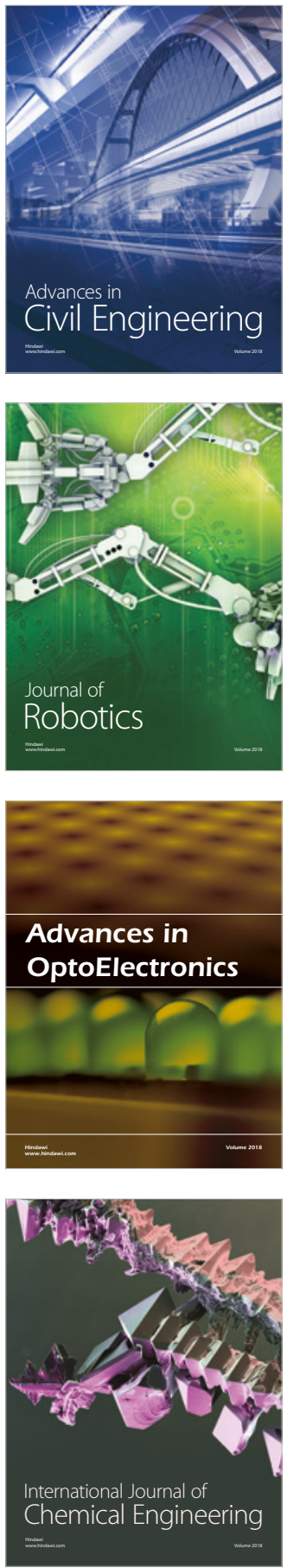

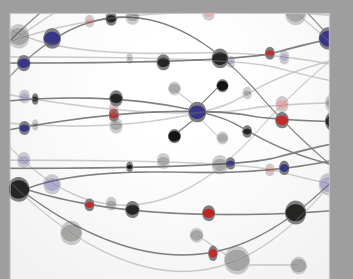

\section{Rotating \\ Machinery}

The Scientific World Journal

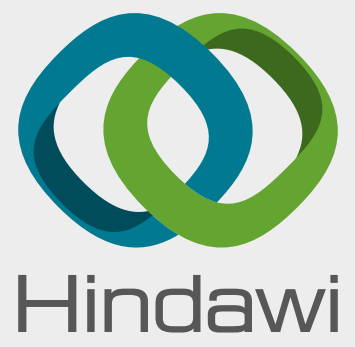

Submit your manuscripts at

www.hindawi.com
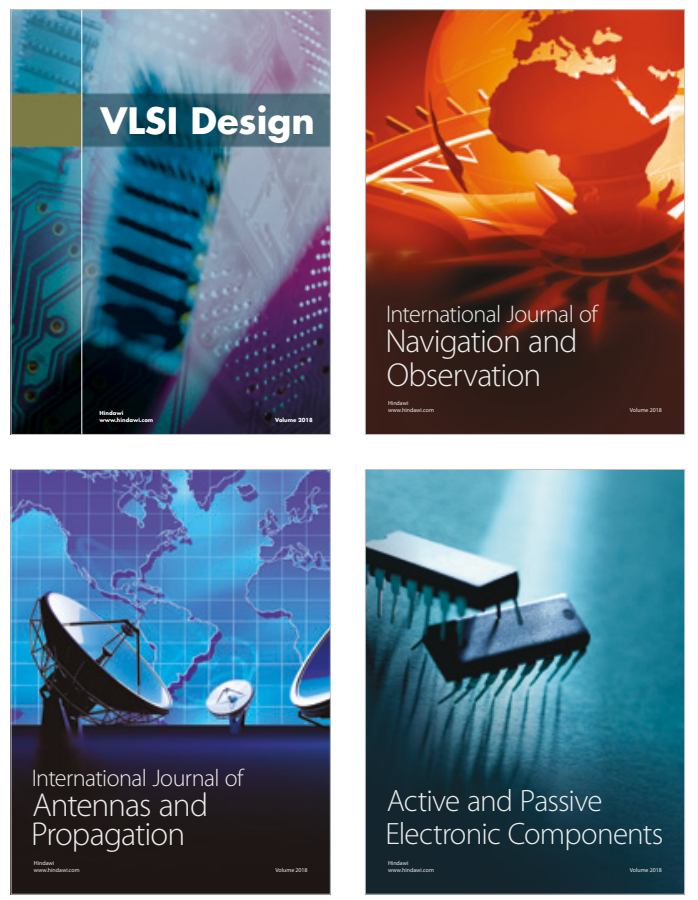
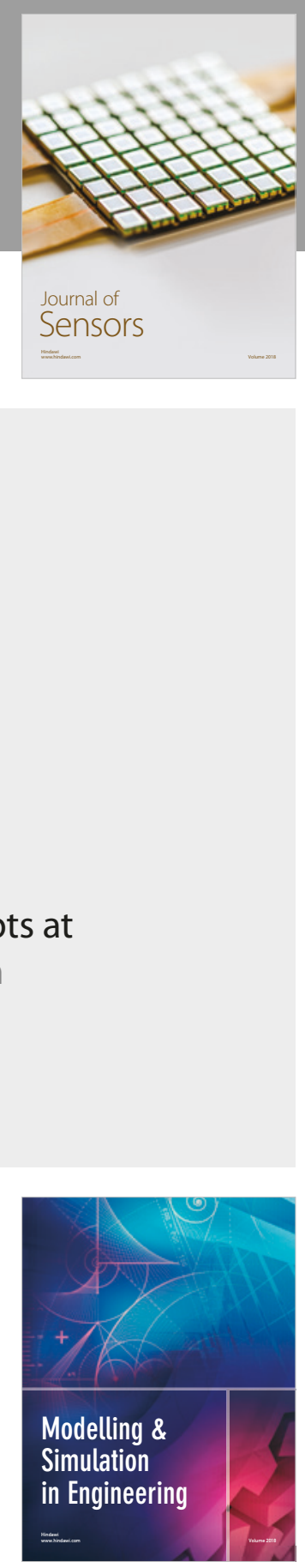

\section{Advances \\ Multimedia}
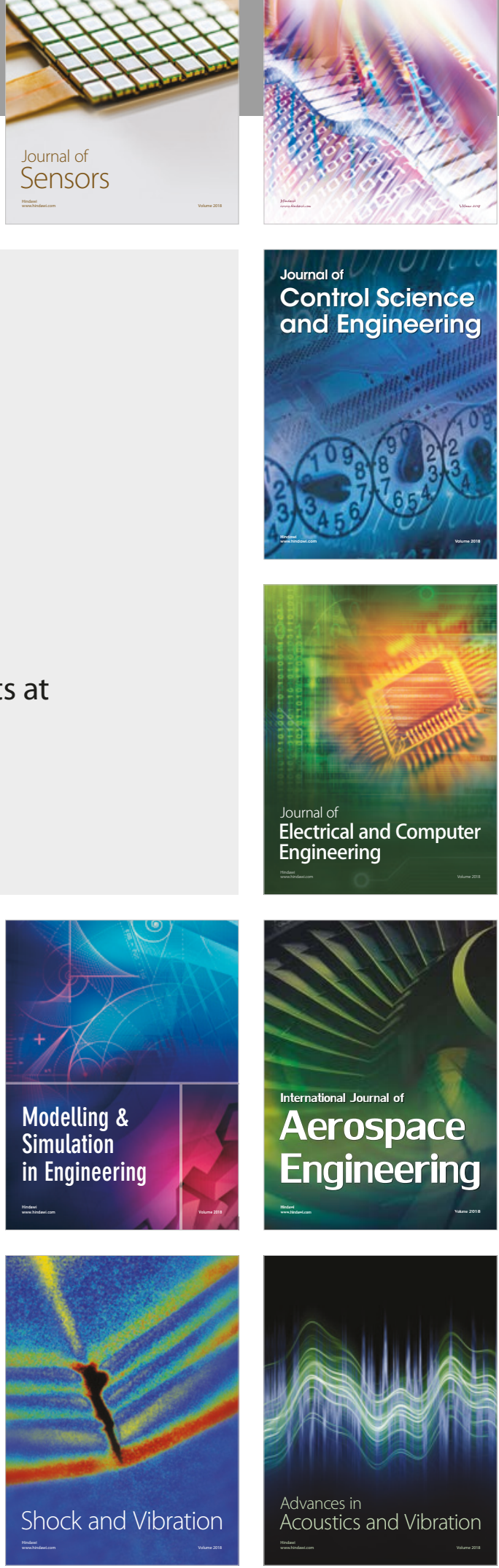